\title{
Química
}

\section{IMÁGENES Y ENSEÑANZA DE LA QUÍMICA. APORTES DE LA TEORÍA COGNITIVA DEL APRENDIZAJE MULTIMEDIA}

\begin{abstract}
Resumen
En este artículo se discute el rol de las imágenes en el aprendizaje y en la enseñanza de la Química. Luego de exponer los principales fundamentos de la Teoría cognitiva del aprendizaje multimedia, y de los 12 principios que se desprenden de ella, se desarrollan sus implicaciones para la enseñanza de la química. Como multimedia se hace referencia a presentaciones o comunicaciones que incluyen palabras e imágenes orientadas a fomentar aprendizajes. Se presenta una clasificación de las imágenes de acuerdo a sus funciones comunicacionales y una secuencia para la "lectura" de una imagen que incluye tres niveles de interpretación de la información contenida en ella. También se aborda la problemática del uso de diagramas y dibujos esquemáticos para el caso de la química. Finalmente, se insta a reformular la relación que los profesores tienen con respecto al uso de las imágenes y a integrar sistemáticamente palabra e imagen en la enseñanza.
\end{abstract}

Palabras clave: imágenes; Teoría cognitiva del aprendizaje multimedia; Enseñanza de la Química

\section{IMAGES AND TEACHING OF CHEMISTRY. CONTRIBUTIONS OF THE COGNITIVE THEORY OF MULTIMEDIA LEARNING}

\begin{abstract}
The role of images in the learning and teaching of Chemistry is discussed in this article. After exposing the main foundations of the Cognitive Theory of Multimedia Learning, and the 12 principles that emerge from it, its implications for the teaching of chemistry are developed. Multimedia makes reference to presentations or communications that include words and images oriented to promote learning. It presents a classification of images according to their communication functions and a sequence for "reading" an image that includes three levels of interpretation of the information contained in it. The problem of the use of diagrams and schematic drawings for the case of chemistry is also addressed. Finally, it is urged to reformulate the relationship that teachers have with respect to the use of images and systematically integrate word and image into teaching.
\end{abstract}

Keywords: images, Cognitive Theory of Multimedia Learning, Teaching of Chemistry

Autor: Andrés Raviolo 


\section{$-a$}

\section{IMÁGENES Y ENSEÑANZA DE LA QUÍMICA. APORTES DE LA TEORÍA COGNITIVA DEL APRENDIZAJE MULTIMEDIA}

\section{Teoría cognitiva del aprendizaje multimedia}

a premisa central de la teoría cognitiva del aprendizaje multimedia es: "Se aprende más profundamente una información si es presentada con palabras e imágenes más que con palabras solas". Esta teoría tiene como principal mentor a Richard Mayer de la Universidad de California, Santa Barbara. En su libro Multimedia Learning (Mayer, 2009) desarrolla de una manera amena y concisa esta teoría y una serie de principios que se desprenden de ella que dan respuesta a la pregunta ¿cómo llevar a cabo una instrucción multimedia efectiva para lograr una mejor comprensión?

Como Multimedia se refiere a presentaciones o comunicaciones que incluyen palabras e imágenes orientadas a fomentar aprendizajes. Se circunscribe a imágenes con fines educativos. Sobre esta base teórica y sobre una rigurosa evidencia empírica, Mayer formula 12 principios para apoyar el aprendizaje de material multimedia, que son especialmente aplicables cuando el material a ser comprendido es complejo y cuando el aprendiz no dispone, o tiene poco, conocimiento previo. Por ello su pertinencia para la química, porque es la situación que se presenta en su enseñanza.

Tres razones justifican esta premisa central:

(1) Imágenes y palabras sobre un contenido no son equivalentes, no dan la misma información. No existe una medida de equivalencia del tipo "una imagen equivale a 1000 palabras", dado que no son redundantes, ni sustituibles. Más bien tienen una naturaleza complementaria, el significado de las palabras se modifica con las imágenes y las palabras dotan de sentido a las imágenes.

(2) La información auditiva/verbal y la información visual/pictórica se retienen y procesan en canales diferentes. El hecho de procesar la información en más de un canal trae ventajas en capacidad, codificación en nuestra memoria y recuperación.

(3) El esfuerzo cognitivo de integrar en la memoria de trabajo palabra e imagen, representaciones verbales y pictóricas, y relacionar con el conocimiento previo, produce aprendizajes más profundos, que van más allá del recuerdo y permiten su aplicación, o transferencia, a otras situaciones o problemas.

La enseñanza basada en esta teoría se pregunta: ¿Cómo las personas aprenden desde recursos multimedia? ¿nncorporar imágenes a las palabras ayuda a las personas a aprender mejor? ¿Qué hace que una imagen sea efectiva? ¿Cuál es la relación entre el diseño de tales recursos y la forma en la que las personas aprenden? ¿Cómo podemos realizar una instrucción multimedia efectiva para lograr una mejor comprensión de un material?

Dar respuesta a estas preguntas requiere conocer cómo esta teoría modeliza el funcionamiento de la mente y el procesamiento de la información, dado que todo diseño de enseñanza multimedia debería ser compatible a cómo las personas aprenden. Este modelo se esquematiza en la Figura 1: 
$-a=$

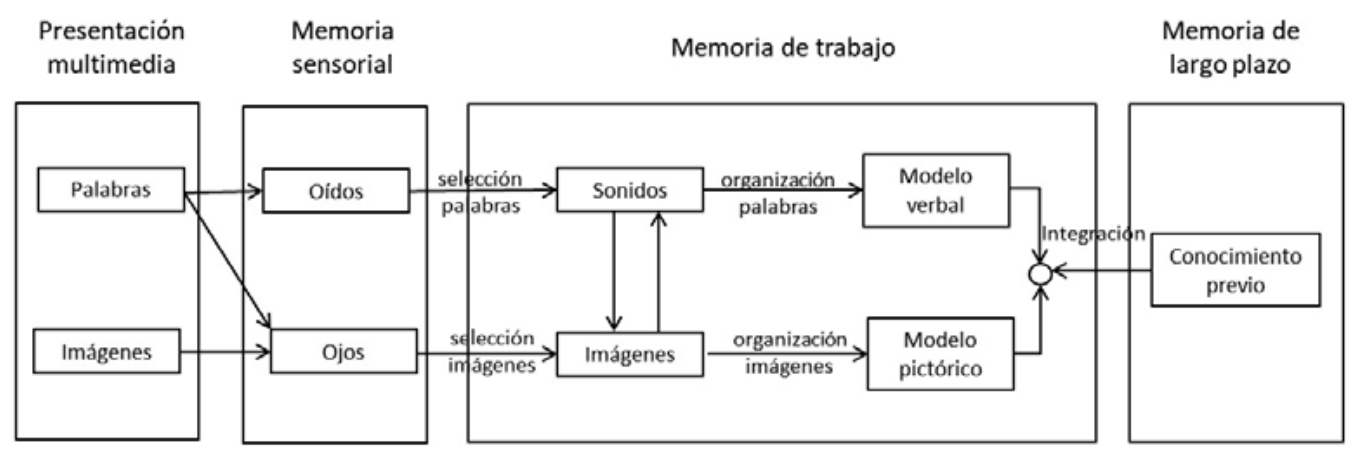

Figura 1: Modelo cognitivo del aprendizaje multimedia (Mayer, 2009).

La mente funciona con dos sistemas de procesamiento de la información, uno para material visual y otro para material verbal y dispone de tres tipos de memoria. La ventaja de procesar la información en dos canales no es algo netamente cuantitativo, sino más bien algo cualitativo, dado que no procesan el mismo material, la información verbal y pictórica no son redundantes, imágenes y palabras no son equivalentes, son complementarias. La comprensión profunda ocurre cuando el aprendiz puede construir conexiones significativas entre las representaciones verbales y pictóricas.

De la presentación multimedia, las palabras son escuchadas por los oídos o leídas por los ojos, las imágenes son vistas por los ojos, en la memoria sensorial se realiza la retención de imágenes y sonidos, atendiendo a la información relevante.

En la memoria de trabajo tiene lugar la actividad principal del aprendizaje multimedia, allí se lleva a cabo el procesamiento de la nueva información la cual se mantiene activamente consciente. La memoria de trabajo permite tener la información que necesitamos mentalmente "a mano" y "manipularla", disponerla en "la mesa de trabajo". Tiene capacidad muy limitada y puede fácilmente sobrecargarse. En cambio, la memoria de largo plazo no tiene límites en su capacidad, ni en cantidad ni en tiempo. En ella se almacena la información proveniente de la memoria de trabajo. Para pensar sobre información almacenada en la memoria de largo plazo ésta debe ser traída a la memoria de trabajo.

En la memoria de trabajo se seleccionan sonidos e imágenes y se organiza la información seleccionada en representaciones mentales coherentes: modelo mental verbal y modelo mental pictórico. Se da sentido a la información integrando representaciones pictóricas con verbales y relacionándolas con el conocimiento previo. Las personas no son receptores pasivos del contenido a aprender, por el contrario, se involucran activamente en procesar la información entrante con el objeto de construir modelos mentales de los conceptos nuevos.

El esfuerzo cognitivo de integrar representaciones verbales y pictóricas, de darles sentido a la luz del conocimiento previo, produce aprendizajes más profundos, que van más allá del recuerdo y reconocimiento, y permiten su aplicación o transferencias a otras situaciones o a la resolución de problemas.

Desde esta perspectiva, el conocimiento previo almacenado en la memoria de largo plazo se activa en el proceso de integración de las representaciones verbales y pictóricas. Esto da una nueva perspectiva para fomentar aprendizajes significativos. La falta de conocimiento previo sobre el tema puede implicar la falta de habilidad para identificar las estructuras relevantes en la visualización multimedia. Los aprendices con un alto nivel de conocimiento previo aportan a la memoria de trabajo información inclusiva 


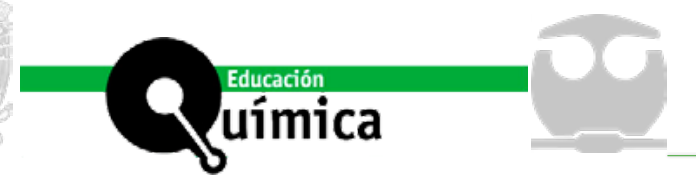

que les permite integrar las representaciones. En cambio, los estudiantes con bajo nivel de conocimiento previo, pueden sobrecargar la memoria cuando enfrentan una tarea compleja que requiere relacionar representaciones múltiples.

En definitiva, la teoría cognitiva del aprendizaje multimedia, descansa en tres suposiciones (Mayer, 2009):

(a) la suposición del canal dual: asume que las personas procesan la información en dos canales separados. En uno la información auditiva/verbal y en otro la información visual/pictórica (Paivio, 1986; Baddeley, 1992). Presentar la información en más de un canal trae ventajas en la codificación y recuperación.

(b) la suposición de la capacidad limitada: afirma que cada uno de esos canales tiene una capacidad limitada. La memoria de trabajo de las personas puede retener un número limitado de palabras e imágenes al mismo tiempo (Chandler y Sweller, 1991; Baddeley, 1992).

(c) la suposición del procesamiento activo: sostiene que las personas se involucran activamente en el aprendizaje atendiendo a la información entrante relevante, organizando la información seleccionada en representaciones mentales coherentes e integrando las representaciones mentales con otro conocimiento (Wittrock, 1989; Mayer, 2008).

Las investigaciones en esta línea condujeron a la formulación de 12 principios del aprendizaje multimedia, cada uno de ellos está fundamentado teóricamente y apoyado en una rigurosa evidencia experimental.

El objetivo de este artículo es reflexionar sobre el rol de las imágenes en el aprendizaje y en la enseñanza de la Química. Las reflexiones se realizan a partir de la presentación de: (a) los 12 principios del aprendizaje multimedia, (b) una clasificación de las imágenes de acuerdo a sus funciones comunicacionales, (c) una secuencia para la "lectura" de una imagen que incluye tres niveles de interpretación de la información contenida en ella y (d) la discusión sobre los diagramas como un tipo de imagen de interés particular.

\section{Principios del aprendizaje multimedia: implicancias para la enseñanza de la química}

Se aprende más profundamente una información si es presentada con palabras e imágenes más que con palabras solas (principio multimedia). Cuando se presentan juntas palabras e imágenes el aprendiz tiene una oportunidad de construir modelos mentales verbales y pictóricos, y conexiones entre ellos. Cuando el material es presentado con palabras solas es menos probable que construya un modelo mental visual y que haga conexiones con el modelo verbal. Esto es muy relevante en el caso de la química, donde generalmente el aprendiz tiene poco conocimiento del tema y, seguramente, necesitará ayuda para construir conexiones entre las representaciones verbales y pictóricas.

Como profesores debemos cambiar nuestra forma de concebir a las imágenes en la enseñanza y empezar a trabajar sistemáticamente con ellas. Que las palabras hagan referencia a imágenes. Esto implica no leer ni hablar en "el aire", en abstracto, o a partir solo de ecuaciones y símbolos. Y que estas imágenes acompañadas de palabras, sean explicadas. 


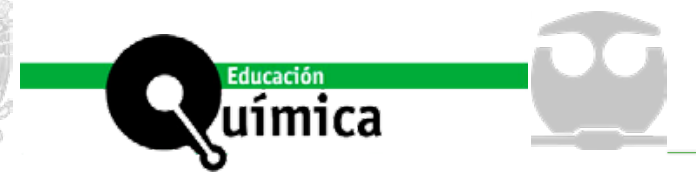

Prestemos atención, en el esquema de la Figura 1, a las flechas que van de sonidos a imágenes que aparecen en el cuadro de la memoria de trabajo. Para el profesor, para un experto, escuchar las palabras "equipo o montaje de destilación" los remite a sus imágenes correspondientes, o cuando ven una imagen como la de la Figura 2 pueden ponerle palabras y explicarla. Con el novato no ocurre lo mismo. Un esquema de un montaje de laboratorio, es percibido por un experto como una sola unidad de información, en cambio, un novato percibe muchas unidades de información, ve distintos materiales en forma independiente. Lo mismo le ocurriría a un profesor ante un montaje desconocido.

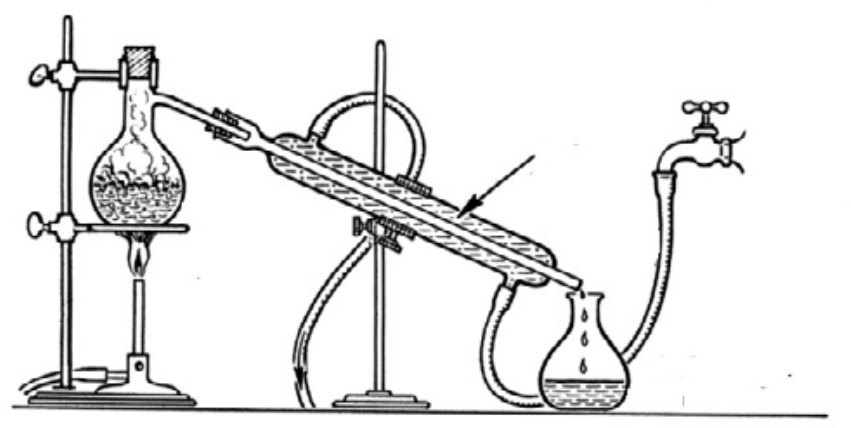

Figura 2: Imagen de un montaje de destilación (Helmenstine, 2018).

Las imágenes que se muestran en este artículo han sido seleccionadas bajo el criterio de ser ejemplos representativos de lo que se argumenta en el texto.

Ante la presentación verbal de un contenido químico, puede pasar que el aprendiz no recurra a ninguna imagen, que procese solo información verbal y produzca un aprendizaje memorístico, con buenos resultados en pruebas de recuerdo, un conocimiento que olvidará pronto. $\mathrm{O}$ que asocie esas palabras a imágenes inadecuadas y genere concepciones alternativas. Las palabras "equilibrio químico dinámico" pueden ser asociadas a imágenes como una balanza en equilibrio, o un sube y baja. Cuando las palabras referidas al equilibrio químico son acompañadas solo de ecuaciones químicas con la doble fecha, los estudiantes pueden construir modelos mentales incorrectos, como los modelos del "equilibrio pendular", del "equilibrio estequiométrico", etc. (Raviolo, 2006). Si en la enseñanza no se presentan imágenes apropiadas del contenido es probable que el estudiante genere sus propias representaciones pictóricas, por ejemplo a través de metáforas o analogías, y dichas imágenes pueden no ser las más adecuadas para articular con las representaciones verbales y conduzca a un conocimiento incorrecto. Con la presentación, por parte del profesor, de imágenes apropiadas aumenta la probabilidad de que se generen aprendizajes más profundos.

Es mejor que la imagen sea acompañada de palabra narrada más que de palabra escrita (principio de la modalidad). De esta forma el canal visual de la memoria de trabajo no procesa imágenes y texto, dado que el canal auditivo procesa la narración. Cuando las palabras se presentan como texto compiten con la imagen por la atención, en el canal visual, con lo cual se divide la atención. Para que la narración sea efectiva debe cumplir el principio de contigüidad temporal que sostiene que palabras e imágenes deben presentarse simultáneamente, al mismo tiempo, en lugar de consecutivamente. Con esto no es necesario mantener en la memoria de trabajo un tipo de representación mientras se logra el acceso al segundo tipo. El sujeto mantiene al mismo tiempo las representaciones verbales y las pictóricas en su memoria de trabajo y con ello es más probable que construya conexiones entre ambas.

Cuando preparamos un material escrito o una diapositiva, o seleccionamos un texto, se debe tener en cuenta el principio de contigüidad espacial que sostiene que se aprende 
mejor la información cuando el texto, y su imagen correspondiente, están físicamente integrados en el texto o en la pantalla. La explicación de una figura debe estar cerca de la misma, los rótulos de cada parte cercanos a lo que nombra. El hecho de, por ejemplo, ubicar las etiquetas o rótulos cerca de los objetos más que en una lista separada, evita realizar búsquedas y, por lo tanto, libera recursos cognitivos.

El principio de redundancia afirma que las imágenes deben ser acompañadas con la narración hablada solamente, sin la presentación de lo que se narra en forma de texto escrito. Cuando no ocurre esto, el aprendiz trata de reconciliar ambas fuentes de información verbal, produciendo una distracción y sobrecarga de memoria. Esto es muy frecuente en las presentaciones de diapositivas cuando se lee de la pantalla textos largos.

Recordemos que esta teoría se refiere a imágenes con fines educativos y por lo tanto no da lo mismo cualquier imagen. El principio de la coherencia afirma que se aprende mejor una información cuando material extraño es excluido más que cuando es incluido. Es mejor excluir palabras e imágenes irrelevantes, por más que puedan ser interesantes. Prescindir también de sonidos y música, de palabras y símbolos innecesarios, de exceso de detalles. La interferencia de material extraño, o innecesario, puede desviar la atención de las ideas centrales y/o saturar la capacidad de procesamiento.

Si la imagen es compleja, con mucha información, o es una imagen dinámica (ej. una simulación) de larga duración sin cortes, es necesario descomponerla en partes y explicar cada una de ellas. El principio de la segmentación afirma que se aprende mejor un material multimedia si es presentado en segmentos pausados por el usuario, que si es presentado en un continuo sin pausa. Este principio es de utilidad para realizar una selección adecuada de imágenes estáticas, animaciones y simulaciones.

Hay que prestar especial atención en que los alumnos conozcan las partes y entidades que participan en el fenómeno químico tratado, los docentes debemos presentar los sujetos o personajes de la historia química que abordamos. El principio de preentrenamiento del aprendizaje multimedia afirma que se aprende más profundamente un mensaje cuando se conoce los nombres y características de los principales conceptos. Además del nombre, es importante la categoría a la cual pertenece, por ejemplo: catión sodio, anión cloruro, disolución de hidróxido de sodio, etc. Las categorías, que sirven para clasificar, resultan claves para definir el concepto; por ejemplo, átomos, iones y moléculas son partículas, disoluciones y sustancias son materia homogénea. Esto ayuda también a ordenar $u$ organizar la información. Al ayudar al aprendiz a adquirir conocimiento previo se disminuye la demanda cognitiva para procesar la información nueva.

También contribuye el uso de ayudas o señalamientos visuales para dirigir la atención del aprendiz a los aspectos claves o relevantes del material. Es decir, orientar la mirada a los sitios o elementos claves de la narración, texto o pantalla. El principio de señalamiento afirma que un material se aprende mejor si se dan pistas que resalten la organización del material. A través del énfasis vocal, de resaltar palabras en el texto, o de señalizar con flechas o círculos partes o entidades, se guía la atención del estudiante a la información relevante del material.

Completan los 12 principios: el principio de la personalización (se aprende mejor una presentación multimedia si se presenta las palabras con un estilo conversacional no formal), el principio de la voz (se aprende mejor cuando la narración es con una voz humana más que con una voz proveniente de máquina) y el principio de la imagen (no se aprende mejor si la imagen del que habla aparece en la pantalla).

La memoria de trabajo es limitada en la cantidad de información y en el tiempo que podemos retenerla y manipularla. No podemos operar con varias cosas a la vez, cosas que requieran nuestra participación activa, al menos que tengamos algunas 
automatizadas, agrupadas como una unidad de información. La percepción de que un material es complejo o no, estará dada, fundamentalmente, por el conocimiento previo, si es un novato o un especialista. Preparar un disolución, es una técnica, que involucra conceptos y procesos. Para un químico es una rutina, en cambio, para un novato no es una tarea sencilla, dado que el aprendizaje de esta técnica implica conocer también los conceptos involucrados (soluto, solvente, disolución, unidades de concentración, materiales de laboratorio, instrumentos de medición). Para el novato esta actividad pone sobre su memoria de trabajo una cantidad de información que sobrepasa su capacidad, o exige que retenga la información por un tiempo excesivo. Como resultado, es muy probable que, inicialmente, presente dificultades en resolver problemas y desempeñarse en el laboratorio exitosamente.

Los estudiantes carecen, generalmente, de imágenes sobre el contenido químico que se enseña. La enseñanza frecuente se basa en palabras, símbolos y ecuaciones. Los estudiantes suelen no contar con imágenes de los sistemas físicos, imágenes macroscópicas o submicroscópicas. Es necesario de que el profesor recurra a imágenes desde el inicio y las acompañe con palabras, de modo de ayudar a los alumnos a organizar la información en representaciones coherentes y a integrarlas entre sí, fomentando que la información tenga sentido, impulsando la vinculación con el conocimiento previo de los estudiantes.

En definitiva, narrar imágenes simples destacando sus partes, componentes, entidades y las relaciones entre ellas, resaltando los puntos centrales, apuntando a los aspectos conceptuales claves, ayudando a relacionar imagen y palabra.

\section{Clasificación de las imágenes de acuerdo a sus funciones comunicacionales}

No toda imagen es igualmente eficiente para fines educativos. El beneficio de usar imágenes dependerá de la calidad de las mismas y de su valor pedagógico (Schnotz y Bannert, 2003).

Las imágenes útiles son las que ayudan a organizar o comprender el material, a darle sentido al material. No toda imagen cumple con esa condición, al respecto resulta esclarecedora la clasificación de Clark y Lyons (2011) (Figura 3). Por ejemplo, imágenes que cumplen funciones decorativas no son útiles, otras no son tan útiles porque, simplemente, cumplen funciones representacionales, como la foto de un objeto. Para fines educativos son más ventajosas las imágenes explicativas, como las organizacionales (que representan relaciones cualitativas entre los contenidos de una lección, como un esquema conceptual o un diagrama con sus componentes etiquetados), las relacionales (que muestran relaciones cuantitativas entre variables, como gráficos y tablas), las imágenes transformacionales (que muestran cambios de un objeto en el tiempo o en espacio, como un video que muestra etapas de un proceso) e imágenes interpretativas (que ilustran relaciones no visibles, que hacen visibles y concretos a fenómenos intangibles, como el uso de un diagrama de partículas -átomos, iones y moléculas-).

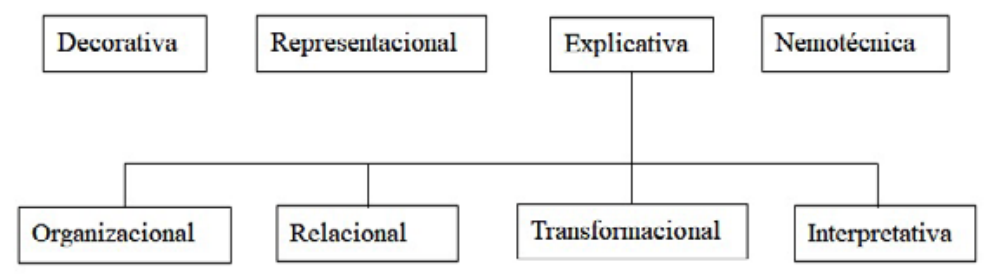

Figura 3: Funciones comunicacionales de las imágenes (Clark y Lyons, 2011). 
Las imágenes nemotécnicas ayudan a recordar los hechos o conceptos de la lección al transferir el significado de un dominio a otro diferente. Imágenes de analogías pueden cumplir esta función, por ejemplo, imágenes de análogos de los modelos atómicos. Este tipo de imagen suele poseer mucha especificidad cultural o lingüística. La imagen humorística de una naranja unida a un grupo metilo hecho con palos y esferas ("naranja de metilo") cumple funciones motivacionales (decorativas) y nemotécnicas (si ayuda a recordar el grupo metilo).

Las tablas que aparecen en los libros de texto son de dos tipos. Algunas son relacionales, relacionan variables cuantitativas, como las tablas de valores, sobre las cuales se pueden confeccionar gráficos cartesianos. Otras son organizacionales, cualitativas, relacionan conceptos, como la tabla de solubilidades, que clasifica en compuestos solubles e insolubles en agua y sus excepciones para cada categoría.

Mayer (1993) analizó libros de ciencias de sexto grado y encontró que aproximadamente la mitad del espacio estaba ocupado por ilustraciones, pero el $85 \%$ de esas ilustraciones correspondían al tipo decorativo y representacional ( 23 y $62 \%$ respectivamente), un $5 \%$ para organizacional y un $10 \%$ para otras funciones explicativas, comprobando que se subestima el potencial de las imágenes para promover el aprendizaje. Con los años los libros de texto de química van incorporando más cantidad de imágenes, con una mayor proporción de imágenes explicativas. Esto pudo apreciarse en libros de texto universitarios de química general, publicados en los últimos 30 años, para el capítulo equilibrio químico (Raviolo, 2016).

No toda imagen es igualmente eficiente para fines educativos. Las imágenes tienen complejidad propia, tienen distintos niveles de interpretación, que pueden generar dificultades para su comprensión.

\section{La "lectura" de una imagen}

Los gráficos cumplen una función relacional, de presentar relaciones cuantitativas entre variables. En el estudio de Postigo y Pozo (2000) sobre cómo interpretan gráficas numéricas adolescentes de 12-16 años, discriminan en tres niveles de aprendizaje: (a) de información explícita, muchos estudiantes se centraron en la interpretación más superficial de la gráfica, (b) de información implícita, que se infiere a partir de la interpretación de las convenciones utilizadas, y (c) de información conceptual, que requiere dar significado a los datos contenidos en la gráfica.

Los gráficos y tablas pueden considerarse como un cuarto nivel de representación, junto con los niveles macroscópico, submicroscópico y simbólico propuestos por Johnstone (1982), por su presencia destacada en los libros de texto y en capturas de pantalla, y por las dificultades específicas que surgen en su aprendizaje. De esta forma se llama la atención sobre la necesidad de enseñarlos, de dedicar un tiempo para explicar su información implícita y conceptual. Por ejemplo, en el siguiente gráfico (Figura 4), se aprecia a nivel explícito mucha información. Además, este gráfico requiere de ayuda para el aprendizaje de la información implícita, dado que las flechas que utilizan se

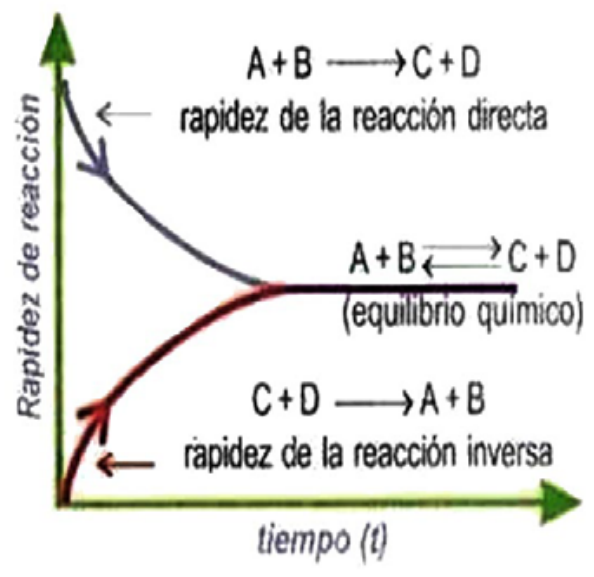

Figura 4: Gráfico que incluye flechas con distintos significados (Sánchez, 2018). 
emplean por lo menos con 5 significados distintos. Luego del comprender los significados que se le asignan a los símbolos empleados (información implícita), la explicación del docente será clave en ayudar a integrar las partes de esta imagen y colaborar al aprendizaje de la información conceptual que, en este caso, explica cómo se alcanza un equilibrio químico y las características del mismo.

En el ejemplo anterior se aprecia que es muy difícil que el aprendiz pueda integrar adecuadamente las representaciones verbales con las pictóricas sin ayuda del profesor, por la cantidad de supuestos implícitos. Esto ocurre con otros tipos de imágenes.

Estos tres niveles de aprendizajes propuestos para gráficos se pueden extender a cualquier imagen (Raviolo, 2018) (Figura 5):

\begin{tabular}{l|l}
\hline \multicolumn{2}{l}{ Niveles de lectura o aprendizaje de una imagen } \\
\hline De información explícita & $\begin{array}{l}\text { Aprendizaje de los aspectos superficiales, } \\
\text { perceptivos, de lo que se ve. }\end{array}$ \\
\hline De información implícita & $\begin{array}{l}\text { Aprendizaje de lo que representa cada parte o } \\
\text { entidad, de las convenciones del simbolismo. }\end{array}$ \\
\hline De información conceptual & $\begin{array}{l}\text { Aprendizaje de los aspectos teóricos } \\
\text { subyacentes, la interpretación global. }\end{array}$ \\
\hline
\end{tabular}

El aprendizaje de la información explícita se refiere a la interpretación de los aspectos superficiales, perceptivos, de lo que se ve. De los trazos o las partes, no por lo que representan. Si se pueden discernir claramente las partes, si es una imagen saturada.

El aprendizaje de la información implícita se refiere a la interpretación de información tácita: lo que representa cada parte, de las convenciones del simbolismo. Para ello, son de utilidad las etiquetas y referencias.

El aprendizaje de la información conceptual se refiere a la interpretación global de la imagen relacionada al propósito por la cual se construyó, los aspectos teóricos subyacentes, la idea básica que pretende transmitir en el contexto educativo.

Para representar el nivel submicroscópico, se suelen utilizar diagramas de partículas que muestran el arreglo de un conjunto de partículas (átomos, iones, moléculas). Los diagramas de partículas son imágenes abstractas que involucran mucha información implícita, que requiere de explicitación o traducción. Por ejemplo, en la imagen de la Figura 8, la información implícita del diagrama de partículas comprende: (a) el circulo magnificado corresponde a un volumen muy pequeño, (b) las esferitas representan átomos de oxígeno, (c) los dos átomos unidos representan una molécula que se mueve en forma compacta, (d) el arreglo, la separación entre las moléculas, indica el estado gaseoso, (e) entre las moléculas hay vacío y (f) la "sombra" indica que la moléculas están en movimiento. La interpretación conceptual hace referencia al modelo del gas ideal, que cumple la teoría cinética molecular. Este tipo de información verbal será clave para integrar imagen y palabra, y dar sentido a la información.

Muchas veces los estudiantes se quedan solo con una lectura superficial o "textual" de la imagen. Generalmente no llegan a la comprensión conceptual de la imagen, porque no tienen conocimiento de la información implícita, de lo que representa cada parte o entidad, de qué está compuesto el sistema estudiado. Como ya se mencionó la interpretación implícita se obstaculiza con el empleo de un mismo símbolo con distintos significados en una imagen, por ejemplo las flechas en la Figura 6 (https://socratic.org/ questions/where-does-reduction-occur-in-a-galvanic-cell).
Figura 5: Niveles de "lectura" o aprendizaje de una imagen. 

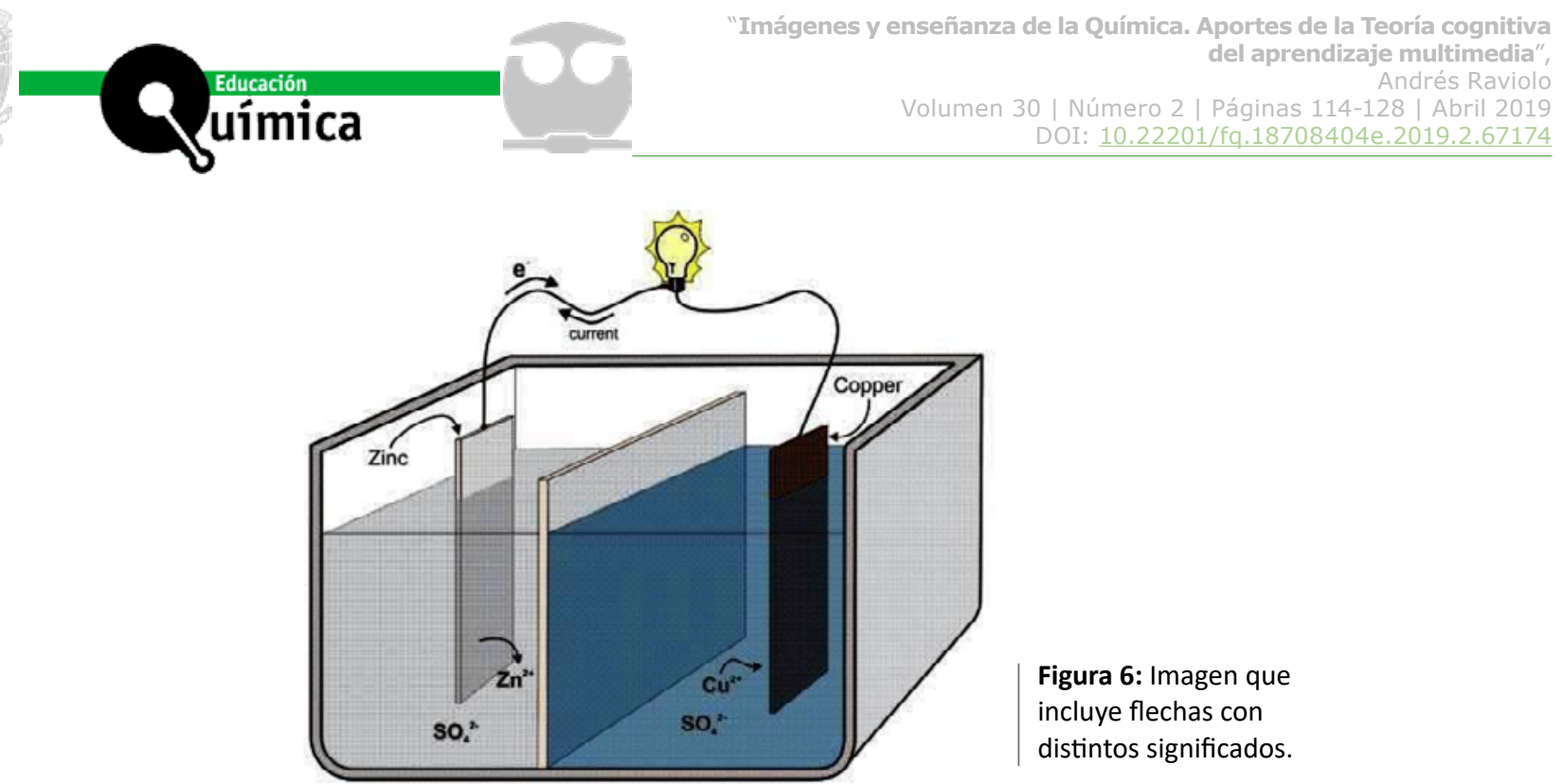

Figura 6: Imagen que incluye flechas con distintos significados.

Otra dificultad para la comprensión de la información explícita de las imágenes está relacionada con las habilidades mentales espaciales que requiere su interpretación. Por ejemplo muchos estudiantes tienen inconvenientes en comprender una sección transversal o en interpretar una imagen en 3 dimensiones a partir de una en 2 dimensiones. La habilidad espacial es la capacidad para generar, retener y manipular imágenes espaciales abstractas (Harle y Towns, 2011) que incluye habilidades mentales de rotación, orientación y visualización. Muchas imágenes, por ejemplo en temas de química orgánica, de cristalografía, etc., son difíciles de procesar para un novato, por su complejidad espacial; es decir, le demanda mucha carga cognitiva organizar la información en representaciones pictóricas adecuadas para darle sentido.

\section{Diagramas y dibujos esquemáticos}

Al respecto de la complementariedad entre imágenes y palabras, merece especial atención un tipo de imagen: los diagramas, también llamados diagramas científicos (Lowe, 1986), dado que cumplen funciones explicativas y, por lo tanto, no pueden prescindir de las palabras. Son esenciales en la enseñanza, tanto en textos como en presentaciones. En un artículo de Educación Química, publicado en el año 1996 pero muy vigente, Solaz se pregunta sobre la eficacia de los diagramas en la instrucción de la ciencia.

Los diagramas son construidos con la intención de mostrar las partes y entidades de un sistema y las relaciones entre ellas. Son ilustraciones simplificadas o esquemáticas en los que prima la representación de las relaciones prescindiendo de los detalles, como el diagrama de un espectrómetro de masas de la Figura 7 (http://www2. montes.upm.es/dptos/digfa/cfisica/ magnet/espectrometro.html). Ya se ha hecho referencia a que se aprende mejor un contenido a partir de imágenes simplificadas más que de imágenes realistas con exceso de información y detalle.

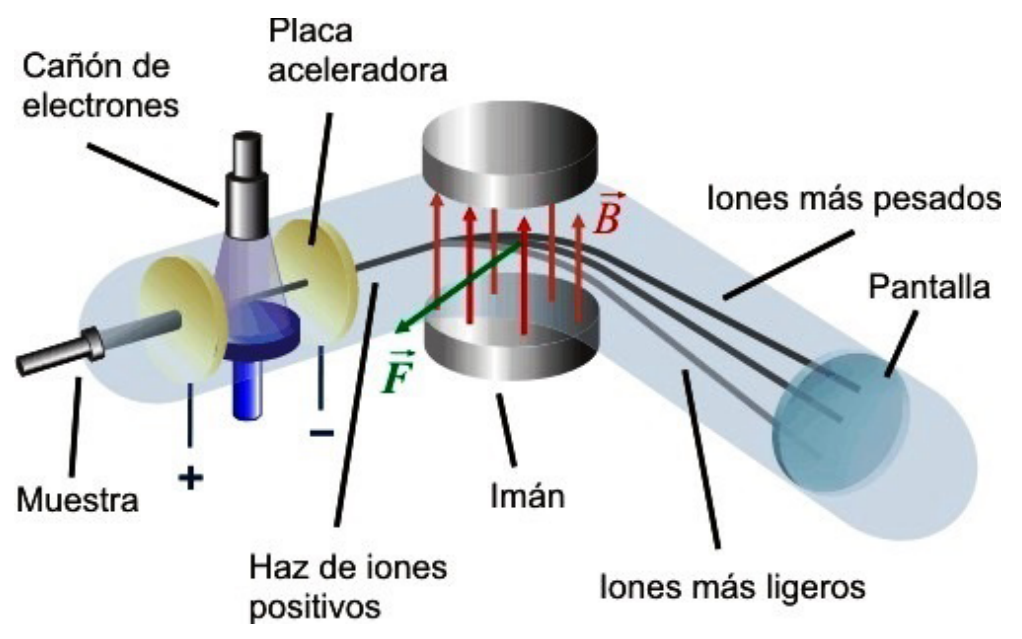




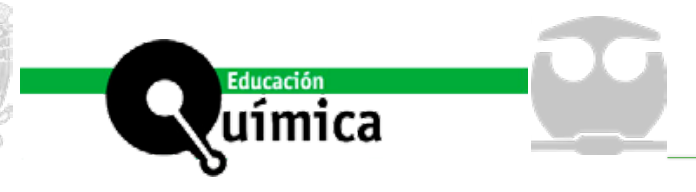

Los dibujos esquemáticos (Perales y Jiménez, 2002) son un tipo de diagrama en los que alguna parte (o partes) del dibujo se corresponden a partes de algún objeto real o entidad. Alguna parte es figurativa, es decir, está presente el nivel de representación macroscópico de la materia. En química estos dibujos también suelen incluir otros niveles de representación como el nivel submicroscópico y el nivel simbólico (Figura 8), aspectos abstractos que no son visibles en los objetos, con lo cual cumplen una función interpretativa. Esto complejiza la lectura de la imagen y requiere de ayuda por parte del docente, una ayuda orientada a identificar e integrar estos distintos niveles de representación. Las explicaciones en química no se limitan solo a interpretaciones a nivel submicroscópico, también se emiten explicaciones centradas en los niveles macro y simbólico poniendo en juego variables o propiedades macro del sistema estudiado (Talanquer, 2011).

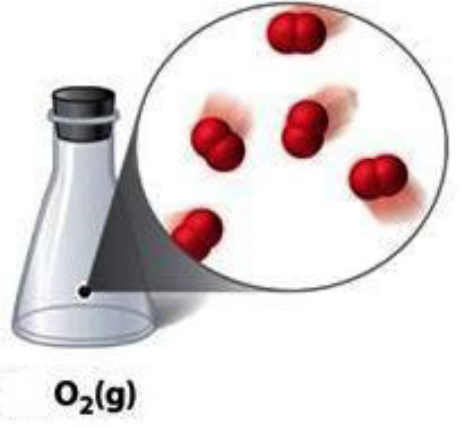

Figura 8: Imagen que integra tres niveles de representación (LibreTexts, 2018).

Estos diagramas combinan realidad y modelo. Constituyen representaciones externas que incluyen visualizaciones de modelos, concebidos como construcciones humanas descriptivas, explicativas y predictivas, lo que fomenta la construcción de modelos mentales de cómo funcionan los sistemas. Los estudiantes presentan dificultades en diferenciar modelo y realidad (Manassero y Vázquez, 1999), en distinguir entre un hecho o fenómeno observado y una inferencia que surge a partir de esas observaciones, de las ideas teóricas que dan sentido a las observaciones. Esto le otorga una "complejidad epistemológica" a las imágenes.

Los diagramas suelen estar acompañados con signos (palabras, números, flechas). Incorporan símbolos que son interpretados por convenciones, por ejemplo los símbolos químicos, o esferas representando átomos, etc. La aparición de símbolos presupone que el estudiante tiene la habilidad de hacer inferencias de acuerdo a una serie de convenciones, fijadas por el especialista autor del diagrama, que le permiten acceder a la información implícita del mismo.

Si bien su interpretación explícita e implícita puede exhibir dificultades, los dibujos esquemáticos tienen una gran potencialidad conceptual, dado que apoyan el aprendizaje de ideas básicas (Raviolo, 2015). Así, la imagen que se muestra a continuación (Figura 9), extraída del texto Química de Chang, persigue el propósito de mostrar que un equilibrio químico heterogéneo no cambia su composición gaseosa (y su presión), a temperatura constante, si se saca o se agrega especies sólidas, siempre y cuando estas especies sólidas estén presentes.

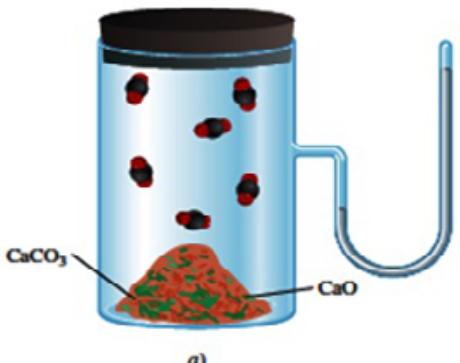

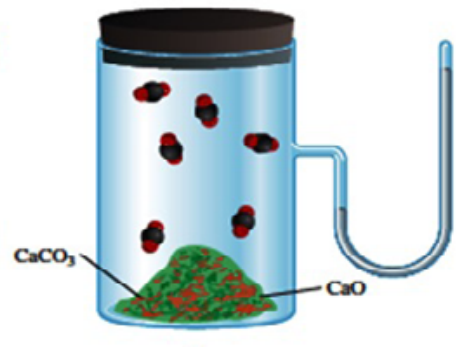

b)
Figura 9: Dibujo esquemático de un equilibrio químico heterogéneo (Chang, 2010). 


\section{$Q_{\text {mina }}$}

Los dibujos esquemáticos constituyen un puente hacia la palabra. En ese recorrido la imagen pierde grado de realismo, aumenta su abstracción y aumenta su intención. Son construidos con un propósito: presentar un aspecto conceptual o recorte de la temática. Los dibujos esquemáticos no son una "captura" directa, no intervenida, de la realidad, por el contrario recurren a gruesas simplificaciones para resaltar una idea.

\section{Discusión del rol de los profesores}

El hecho de que como profesores no le otorgamos a las imágenes el lugar que merecen y centremos nuestra enseñanza en las palabras y los símbolos se basa, en parte, en nuestras creencias respecto al rol de imagen en educación. Varios autores han advertido sobre la "imagen" que se tiene de la imagen como producto de concepciones psicológicas o pedagógicas ingenuas (Otero et al, 2003; Perales y Jiménez, 2002; Matus Leites et al, 2008).

Si a toda imagen le adjudicamos los atributos de una foto, imagen reproductiva, concebiremos las imágenes como "auto evidentes", "transparentes" y por tanto, que no necesitarán explicación. Creeremos que las imágenes más realistas, de mayor semejanza a lo que representan, o las que posean mayor grado de detalle, serán las mejores para el aprendizaje.

Al soslayar la naturaleza construida de la mayoría de las imágenes que se presentan en la química, no abordaremos la complejidad epistemológica de las mismas, dado que combinan realidad y modelo. Asumiremos que las imágenes representan un conocimiento "verdadero" dado que está a la vista la "evidencia", bajo la suposición de "ver para creer". Fomentaremos la noción errónea de que los modelos son copias de la realidad, que un modelo es mejor cuanto más se parezca a lo que representa.

De estas creencias se desprende una concepción de aprendizaje que sostiene que hay una relación directa entre representaciones externas e internas, que las ilustraciones se almacenan como fotos en la cabeza, que su aprendizaje es por impregnación pasiva, minimizando el rol mental activo del aprendiz.

Si concebimos a las imágenes como más "sencillas" que las palabras, asumiremos que éstas se recordarán y comprenderán más fácilmente y serán más adecuadas para los niveles educativos iniciales. De este modo estaremos obviando las dificultades intrínsecas que suelen poseer las imágenes. También descansaremos en la función motivacional de las imágenes y en el ilusorio rol de que ayudan a los estudiantes menos dotados intelectualmente.

La teoría cognitiva del aprendizaje multimedia nos revela que se producen aprendizajes más profundos cuando se integran, en la memoria de trabajo, palabras e imágenes, representaciones verbales y pictóricas, y se relaciona con el conocimiento previo. Ante un contenido complejo y estudiantes sin conocimiento previo, es necesario que los profesores muestren imágenes, las expliquen facilitando su integración. Es necesario crear las condiciones para que los estudiantes pregunten con frecuencia: "Profesor: ¿qué estamos viendo? ¿de qué está hablando?" con ello estarían demandando la presentación de imágenes de los sistemas que se están abordando y de las palabras que les dan sentido.

De acuerdo a Solaz (1996), para que se aprenda a partir de diagramas los profesores deberían: (1) dar a conocer las convenciones que se emplean en su construcción, (2) explicarlos convenientemente, (3) interconectar con el resto de la información proporcionada, (4) trabajar mediante actividades como cuestiones y problemas y (5) diferenciarlos de los modelos científicos y de la realidad física. Los dibujos esquemáticos 
más adecuados serán los que den cuenta de una o pocas ideas básicas (Raviolo, 2015). ¿Contamos con diagramas apropiados para presentar cada una de las ideas básicas o centrales de cada temática que abordaremos en la enseñanza?

Preguntas como: ¿cuál era la equivalencia entre $\mathrm{cm}^{3}$ y litro?, nos indica que los estudiantes no cuentan con imágenes de las unidades de medida, no visualizan $\mathrm{al}^{\mathrm{cm}}$ como un "dado", como un cubo de $1 \mathrm{~cm}$ de arista, que tiene una capacidad de un mililitro. La pregunta: ¿cuál era la fórmula de la densidad? está expresando que no visualizan a la densidad como la masa de un $\mathrm{cm}^{3}$ de esa sustancia.

Durante la enseñanza se sugiere mostrar imágenes, por ejemplo en presentaciones con diapositivas, y dar un tiempo para que los estudiantes las describan y expliquen; o entregar imágenes impresas en papel a grupos de alumnos para que las discutan. En ambos casos el profesor evalúa las respuestas y brinda apoyo sobre la información implícita y conceptual.

Este posicionamiento didáctico se tendría que manifestar en la evaluación, incorporando imágenes en una forma sistemática. Añadiendo problemas acompañados de ilustraciones o situaciones problemáticas realizadas con capturas de pantalla. En los exámenes finales presentar diagramas, tablas, gráficos y pedirles a los alumnos que los expliquen, primero en forma escrita y luego oralmente. Con preguntas orientadas el docente puede evaluar el grado de integración y adecuación entre representaciones verbales y pictóricas y su relación con el conocimiento previo. En este sentido será útil que el profesor prepare un banco de imágenes en color y reemplace ítems de evaluación tradicional, como ejercicios numéricos, por este tipo de actividad conceptual. Con ello la evaluación se constituye en una instancia de aprendizaje no solo de acreditación.

En este artículo, se ha ejemplificado, fundamentalmente, con imágenes estáticas, en una segunda parte, nos enfocaremos en la enseñanza de procesos a partir de imágenes dinámicas, como animaciones y videos.

\section{Conclusiones}

La química es una ciencia visual (Wu y Shah, 2004) que posee un contenido educativo complejo debido a: vocabulario específico, cantidad de información, abstracción, simbolismo, habilidad espacial, etc. Contenido que se presenta a estudiantes que generalmente no cuentan con un conocimiento previo, que no disponen de imágenes de los sistemas o entidades que se van a abordar. Dar respuesta a esta problemática, del aprendizaje de un contenido complejo por parte de un aprendiz sin conocimiento previo, es a lo que principalmente apunta la Teoría Cognitiva del Aprendizaje Multimedia, por ello su particular relevancia para el aprendizaje y la enseñanza de la química, con respecto a otros enfoques que abordan el tema de la imagen con otros propósitos como la percepción, los sentimientos y/o el arte (Aumont, 1992; Berger, 2000 y Grüner, 2002).

Como se mencionó al comienzo, esta teoría cognitiva reúne aportes de otras teorías que abordan la cuestión de las imágenes en el aprendizaje. Toma de la teoría de la codificación dual de Paivio (1986) la idea de que los textos combinados con imágenes conducen a estructuras cognitivas más elaboradas que los textos sin imágenes; de la teoría de la memoria de trabajo de Baddeley (1999) la idea de que en la memoria de trabajo se procesan porciones del material presentado, tanto de imágenes como texto, más que una copia exacta (visual o auditiva); y de la teoría del proceso generativo de Wittrock (1989) la idea de que el resultado del procesamiento cognitivo activo es la construcción de representaciones mentales coherentes. 
La idea central que se ha desarrollado en este artículo es que se aprende más profundamente una información si es presentada con palabras e imágenes más que con palabras solas. Palabra e imagen dan información complementaria, el significado de las palabras se modifica con las imágenes y las palabras dotan de sentido a las imágenes. El proceso de integrar palabras e imágenes relevantes es un paso clave en el aprendizaje significativo, dado que activa el conocimiento previo. Esa integración se favorece con preguntas adecuadas por parte del profesory un diseño apropiado basado en los principios del aprendizaje multimedia. Se ha profundizado en que no da lo mismo cualquier imagen y que las palabras deben dar cuenta de la información explícita y también de la implícita.

Una enseñanza basada en palabras y símbolos, sin experimentos ni manipulación de materiales y con pocas visualizaciones macro y micro de los sistemas, hace que los estudiantes no cuenten con imágenes mentales, o cuenten con inadecuadas, de los sistemas físicos y químicos que se están abordando, hace que los estudiantes se desempeñen "a ciegas".

Como profesores debemos cambiar nuestra forma de concebir a las imágenes en la enseñanza y empezar a trabajar sistemáticamente con ellas. Que las palabras hagan referencia a imágenes. Seleccionar imágenes adecuadas atendiendo a que la información explícita esté fácilmente perceptible, aportando las referencias y demás información implícita pertinente, de forma de allanar el camino al aprendizaje conceptual.

\section{Bibliografía}

Aumont, J. (1992). La imagen. Barcelona: Paidós.

Baddeley, A. D. (1992). Working memory. Science, 255, 556-559.

Baddeley, A. D. (1999). Human memory. Boston: Allyn \& Bacon.

Berger, J. (2000). Modos de ver. Barcelona: Gustavo Gili.

Chandler, P. y Sweller, J. (1991). Cognitive load theory and the format of instruction. Cognition and Instruction, 8, 293-332.

Chang, R. (2010). Química (10 Edición). México: Mc Graw Hill.

Clark, R. y Lyons, C. (2011). Graphics for learning (2nd ed.). San Francisco: Pfeiffer.

Grüner, E. (2002). El sitio de la mirada. Secretos de la imagen y silencios del arte. Buenos Aires: Norma.

Harle, M. y Towns, M. (2011). A review of spatial ability literature, its connection to chemistry, and implications for instruction. Journal of Chemical Education, 88, 351-360.

Helmenstine, A. (2018). How to set up distillation apparatus. En la URL https://www. thoughtco.com/how-to-set-up-distillation-apparatus-606046

Johnstone, A. H. (1982). Macro- and microchemistry. School Science Review, 64, 377-379.

Larkin, J. y Simon, H. (1987). Why a diagram is (sometimes) worth ten thousand words. Cognitive Science, 11, 65-99.

LibreTexts, (2018). Chemistry. Classifying matter according to Its state. En la URL https://chem.libretexts.org/Textbook_Maps/Introductory_Chemistry/ Map\%3A_Introductory_Chemistry_(Tro)/03\%3A_Matter_and_Energy/3.03\%3A_ Classifying_Matter_According_to_Its_State\%3A_Solid\%2C_Liquid\%2C_and_Gas

Lowe, R. (1986). The scientific diagram: is it worth a thousand words? Australian Science Teachers Journal, 32(3), 7-1.

Manassero, M. y Vázquez, A. (1999). Ideas de los estudiantes sobre la epistemologíade la ciencia: modelos, leyes y teorías. Revista de Educación, 320, 309-334. 
Matus Leites, L., Benarroch, A. y Perales, F. (2008). Las imágenes sobre el enlace químico usadas en los libros de texto de educación secundaria. Análisis desde los resultados de la investigación educativa. Enseñanza de las Ciencias, 26(2), 153-176.

Mayer, R. E. (1993). Illustrations that instruct. In R. Glaser (Ed.), Advances in Instructional Psychology (vol. 4, pp. 253-284). Hillsdale, NJ: Erlbau.

Mayer, R. E. (2008). Learning and instruction (2nd ed.). Upper Saddle River, NJ: Pearson Merrill Prentice Hall.

Mayer, R. E. (2009). Multimedia learning (2nd ed.). New York: Cambridge University Press.

Otero, M., Greca, I. y Lang da Silveira, M. (2003). Imágenes visuales en el aula y rendimiento escolar en Física: un estudio comparativo, Revista Electrónica de Enseñanza de las Ciencias, 2, 1-30.

Paivio, A. (1986). Mental representations: A dual-coding approach. Oxford, England: Oxford University Press.

Perales, F. y Jiménez, J. (2002). Las ilustraciones en la enseñanza-aprendizaje de las ciencias. Análisis de libros de texto. Enseñanza de las Ciencias, 20(3), 368-386.

Postigo, Y. y Pozo, J. I. (2000). Cuando una gráfica vale más que 1.000 datos: la interpretación de gráficas por alumnos adolescentes. Infancia y Aprendizaje, 90, 89-110.

Raviolo, A. (2006). Las imágenes en el aprendizaje y en la enseñanza del equilibrio químico, Educación Química, 17(no extraordinario), 300-307.

Raviolo, A. (2015). Los dibujos esquemáticos en la enseñanza y aprendizaje de las ciencias. Novedades Educativas, 295, 66-70.

Raviolo, A. (2016). Las imágenes en libros de texto universitarios: el capítulo equilibrio químico. Educación en la Química, 22(1), 26-38.

Raviolo, A. (2018). La imagen en la enseñanza de la Química y principios del aprendizaje multimedia. Conferencia plenaria, XVIII Reunión de Educadores en la Química. Río Cuarto, Argentina.

Sánchez, J. (2018). Equilibrio químico. Cosas de Física y de Química. En la URL http:// elfisicoloco.blogspot.com/2012/11/equilibrio-quimico-ley-de-accion-de.html

Schnotz, W. y Bannert, M. (2003). Construction and interference in learning from multiple representation. Learning and Instruction, 13,141-156.

Solaz, J. (1996). Diagramas: ¿ilustraciones eficaces en la instrucción en ciencias? Educación Química, 7(3), 145-149.

Talanquer, V. (2011). Macro, submicro, and symbolic: The many faces of the chemistry "triplet". International Journal of Science Education, 33(2), 179-195.

Wittrock, M. C. (1989). Generative processes of comprehension. Educational Psychologist, 24, 345-37.

Wu, H. y Shah, P. (2004). Exploring visuospatial thinking in chemistry learning. Science Education, 88(3), 465-492. 